\title{
Effect of Nitrogen Fertilization on Growth and Yield of Industrial Hemp (Cannabis sativa L.)
}

\section{Panayiota PAPASTYLIANOU*, Ioanna KAKABOUKI, Ilias TRAVLOS}

\author{
Agricultural University of Athens, Faculty of Crop Science, 75 Iera Odos, 11855, Athens, \\ Greece;ppapastyl@aua.gr ('correspondingauthor); i.kakabouki@gmail.com; travlos@aua.gr
}

\begin{abstract}
Fibre hemp is grown for a multitude of end products derived from its cannabinoids, seed, fibre and wooden core. A key factor that influences the quantity and quality of the production of hemp is nitrogen fertilization. The aim of this study was to determine the response of five well-adapted industrial hemp cultivars to different nitrogen fertilization rates during the 2016 growing season. The experiment was laid out in a split-plot design with two replicates, five main plots (hemp cultivars: 'Bialobrzeskie', 'Tygra', 'Felina 32', 'Sanhtica 27', 'Futura 75') and sub-plots [fertilization treatments: control (N0), fertilizer 46-0-0 at $120 \mathrm{~kg} \mathrm{ha}^{-1}(\mathrm{~N} 1), 180 \mathrm{~kg} \mathrm{ha}^{-1}(\mathrm{~N} 2), 240 \mathrm{~kg} \mathrm{ha}^{-1}(\mathrm{~N} 3)$ ]. For the computation of height, biomass yield, stem dry weight, length and weight of the inflorescences and mean seed weight, 10 plants were randomly selected in each plot. In general, increasing $\mathrm{N}$ fertilization rate positively impacts hemp biomass yield, stem dry weight, plant height, and inflorescence indices. Biomass yield, stem dry weight and inflorescence weight increased by $37.3 \%, 48.2 \%$ and $16 \%$, respectively, with the application of $240 \mathrm{~kg} \mathrm{~N} \mathrm{ha}^{-1}$ when compared with the unfertilized control. Plant height and inflorescence length increased from 1.66 to $1.76 \mathrm{~m}$ and from 66.2 to $82.9 \mathrm{~cm}$, respectively, with the application of the higher $\mathrm{N}$ rate compared with the control, while there were no significant differences between the fertilization treatments for mean seed weight. The varieties 'Tygra' and 'Futura 75' showed the highest values for all the measurement characters. Our results indicate that hemp responded well to the addition of $\mathrm{N}$ fertilizer.
\end{abstract}

Keywords: biomass yield, Cannabis sativa, hemp cultivars, inorganic fertilization, seed weight

\section{Introduction}

Hemp (Cannabis sativa L.) an annual crop of central Asian origin, is considered one of the oldest plant sources for food, oil, textile fiber and medicinal chemicals and is estimated to have been utilized for over 10.000 years. In Europe, it was one of the most important fiber crops from the $16^{\text {th }}$ to $18^{\text {th }}$ century, but from the middle through to the late $19^{\text {th }}$ century the cultivation of hemp in Europe declined. The major factors, which contributed to the reduction of cultivated area, were the competition from other feedstocks such as cotton and, more recently, synthetic fibers, high labor costs, and the prohibition of cultivation due to the use of cannabis as a narcotic (Struik et al., 2000; Amaducci et al., 2015). Nowadays, a renewed interest in hemp cultivation for multipurpose production is apparent and for the first time in 2015, it was cultivated in Europe on more than 20.000 ha as a dual-purpose crop, for its seeds and fibre (Tang et al., 2016). As well as traditional uses, modern hemp harvests are utilized in a variety of products such as: textiles for apparel and cottonized hemp, mats for thermal insulation in the construction industry, specialty pulp and paper for technical applications, press-moulded interior panels for the automotive industry, geotextiles for erosion control, needle-punched carpeting, hurds used as animal bedding and construction materials. In addition, industrial hemp can be used in seed and oil for the food sector, natural body care products, gamma linolenic acid in the cosmetics and pharmaceutical industries, natural THC-based therapeutic drugs, alternative energy applications (biogas, biodiesel and solid fuel) and decontamination of heavy metal-polluted soils. The global market for hemp is estimated at more than 25,000 products. (Amaducci and Gusovius, 2010; Salentijn et al., 2015).

Fibre hemp in Greece was commonly grown in the 1930 s and 1940s for production of technical textiles such as twine, ropes, tarpaulin, non-wovens, plumber fibre, sacks, etc. After 1957 its cultivation was forbidden due to problems with its narcotic properties, such as $\Delta-9$ tetrahydrocannabinol (THC). In 2016 the cultivation of industrial hemp was again permitted but under strict control and monitoring by the Ministry of Rural 
198

Development and Food. Recently there has been increasing interest in the reintroduction of fibre hemp into the ordinary cropping system due to several ecological, agronomic and industrial features. Indeed, fibre hemp appears to be an appealing crop for the Mediterranean environment both because it may reduce cereal monocropping, which decreases the chemical, physical and biological fertility of soil and because it may serve to control weeds, diseases, and pests (Cosentino et al., 2013).

In relation to the environment, fibre hemp can be grown under a wide range of agro-ecological conditions, but it requires special attention to several physiological features, crop management and site-specific selection of genotypes. Its introduction in Southern Europe requires the choice of an appropriate genotype, management practices and sowing time. The literature suggests that the effect of nitrogen fertilization on hemp yield is larger than the effect of phosphorus and potassium. Experimental results confirm that nitrogen fertilization should be determined based on soil fertility in fact, the yield response of hemp to supplemental nitrogen was negligible in rich soils (Struik et al., 2000; Prade et al., 2011). In contrast, significant yield increases were reported in nitrogen limiting conditions (Van der Werf et al., 1995; Struik et al., 2000; Amaducci et al., 2002; Aubin et al., 2015). Vera et al. (2010, 2004) reported that hemp seed yield increased progressively with increasing nitrogen availability under a high fertilization rate, which ranged from $99 \mathrm{~kg} \mathrm{~N} \mathrm{ha}^{-1}$ to $198 \mathrm{~kg} \mathrm{~N} \mathrm{ha}^{-1}$ depending on growing conditions. According to several studies conducted in the Netherlands, England, Latvia and Italy, nitrogen fertilization rates ranged between 100 and $240 \mathrm{~kg} \mathrm{~N} \mathrm{ha}{ }^{-1}$, while the highest bast fiber yields were obtained at nitrogen rates between 50 and $150 \mathrm{~kg} \mathrm{~N} \mathrm{ha}^{-1}$ (Van der Werf et al., 1995; Struik et al., 2000; Sausserde \& Adamovics, 2013; Aubin et al., 2015).

The lack of agronomic guidelines for Greek conditions is however, a limiting factor for local hemp production. There is thus a need to establish optimal local agronomic practices for industrial hemp production to optimize biomass and seed yields. The aim of this study was to determine the response of five well-adapted industrial hemp cultivars to different nitrogen fertilization rates during the 2016 growing season.

\section{Materials and Methods}

\section{Experimental site and weather conditions}

A field experiment was carried out at the Agricultural University farm located in Athens (southern Greece: latitude $37^{\circ} 58^{\prime} \mathrm{N}$, longitude $23^{\circ} 32^{\prime} \mathrm{E}$, altitude $30 \mathrm{~m}$ above sea level) during the 2016 growing season. The soil was clay loam $(29.3 \%$ clay, $33.8 \%$ silt and $36.9 \%$ sand) with $\mathrm{pH} 7.17$, nitrate-nitrogen $\left(\mathrm{NO}_{3}-\mathrm{N}\right) 12.4 \mathrm{mg} \mathrm{kg}^{-1}$ soil, available phosphorus $(\mathrm{P}) 13.2 \mathrm{mg}$ $\mathrm{kg}^{-1}$ soil, available potassium (K) $201 \mathrm{mg} \mathrm{kg}^{-1}$ soil and $1.17 \%$ organic matter. Weather data (rainfall, maximum and minimum air temperatures) were recorded daily and are reported as mean monthly data for the period in which the study was conducted (Table 1). Average air temperatures during the growing period did not vary considerably from the long-run averages; however, during June, July and August 2016 the average and maximum temperatures were higher than the normal. Long-term mean annual rainfall at the site is $401 \mathrm{~mm}$, but temporal variability is high. There was no rainfall from July to August 2016 and only 1.6 and $6.8 \mathrm{~mm}$ of rain in May and September, respectively. Above-normal rainfall occurred in October. Total rainfall during the experimental period was 94 $\mathrm{mm}$. These variations are typical for the Mediterranean climate, which is characterized by a long, hot and dry summer during which full irrigation is essential for growing crops.

\section{Experimental design and treatments}

The experimental design was split plot, with five European hemp cultivars characterized by different origin and maturity group (Table 2) as the main plots and fertilization treatments as the sub-plots in a randomized complete block design replicated two times. The fertilizer treatments consisted of four $\mathrm{N}$ rates [control (N0), $120 \mathrm{~kg} \mathrm{ha}^{-1}(\mathrm{~N} 1), 180 \mathrm{~kg} \mathrm{ha}^{-1}$ (N2), and $\left.240 \mathrm{~kg} \mathrm{ha}^{-1}(\mathrm{~N} 3)\right]$. To obtain three levels of initial availability equal to the rates mentioned above, nitrogen was distributed as urea 46-0-0 before sowing. The plot size of each fertilization treatment was $20 \mathrm{~m} \times 4 \mathrm{~m}$ and the experimental plots were 4 $\mathrm{m} \times 5 \mathrm{~m}$ and consisted of 20 rows $0.20 \mathrm{~m}$ apart. Seeds were hand-planted at $3 \mathrm{~cm}$ depth on 25 May 2016 in order to achieve the planned crop density of 125-130 plants per $\mathrm{m}^{2}$ with wheat (Triticum turgidum subsp. durum L.) as the preceding crop. A drip irrigation system was installed in the experimental plots, watering when necessary, and the crop was kept free of weeds by hand hoeing.

Table 1. Monthly means of maximum $\left(\mathrm{T}_{\max }\right)$, minimum $\left(\mathrm{T}_{\min }\right)$ and average $\left(\mathrm{T}_{\text {average }}\right)$ air temperatures $\left({ }^{\circ} \mathrm{C}\right)$ and total rainfall $(\mathrm{mm})$ in the experimental site for 2016 and the 30-year average (1986-2016)

\begin{tabular}{|c|c|c|c|c|}
\hline Month & $\mathrm{T}_{\max }\left({ }^{\circ} \mathrm{C}\right)$ & $\mathrm{T}_{\min }\left({ }^{\circ} \mathrm{C}\right)$ & $\mathrm{T}_{\text {average }}\left({ }^{\circ} \mathrm{C}\right)$ & Rainfall (mm) \\
\hline \multicolumn{5}{|c|}{$1987-2016$} \\
\hline May & 25.5 & 15.5 & 20.3 & 5.0 \\
\hline June & 30.0 & 19.8 & 24.8 & 22.6 \\
\hline July & 32.8 & 22.8 & 27.5 & 21.8 \\
\hline August & 32.5 & 22.7 & 26.9 & 2.8 \\
\hline September & 29.1 & 19.3 & 23.9 & 20.8 \\
\hline October & 23.1 & 14.9 & 18.3 & 39.0 \\
\hline \multicolumn{5}{|c|}{2016} \\
\hline May & 33.3 & 12.9 & 21.3 & 1.6 \\
\hline June & 39.8 & 18.3 & 27.7 & 25.2 \\
\hline July & 36.1 & 32.2 & 29.5 & 0 \\
\hline August & 36.9 & 22.3 & 28.9 & 0 \\
\hline September & 32.8 & 15.6 & 24.5 & 6.8 \\
\hline October & 31.9 & 12.7 & 20.0 & 60.4 \\
\hline
\end{tabular}


Table 2. Origin, sexual type and maturity group of the hemp cultivars used in the research (seed showed a legal THC content i.e. $<0.2 \% \mathrm{w} / \mathrm{v}$ )

\begin{tabular}{cllc}
\hline Cultivar & Origin & Sexual type & Maturity group \\
\hline 'Bialobrzeskie' & Poland & Monoecious & Early \\
'Felina 32' & France & Monoecious & Early \\
'Tygra' & Poland & Monoecious & Medium \\
'Sanhtica 27' & France & Monoecious & Late \\
'Futura 75' & France & Monoecious & Late \\
\hline
\end{tabular}

\section{Plant measurements}

At harvest time (17 October), samples from 10 plants were taken randomly from the middle rows of the plots and different characteristics such as plant height, biomass yield, stem dry weight, length and weight of the inflorescences and mean seed weight were recorded. Plant samples were cut above soil level and plant height and fresh biomass were determined. The samples were separated into two fractions: stems and the remaining part (green and yellow leaves and inflorescence) and weighed. In order to determine the dry weight of stems subsamples were oven dried at $105^{\circ} \mathrm{C}$ until their weight remained constant. Seed weights were obtained by taking the mean weights of batches of 100 seeds.

\section{Data analysis}

The data were subjected to statistical analysis according to the split-plot design (STATGRAPHICS Plus 5.1 logistic package). Differences between treatment means were compared at $\mathrm{P}=5 \%$ with ANOVA in order to find the statistically significant differences.

\section{Results and Discussion}

The analysis of variance of our data revealed that all traits except mean seed weight were significantly affected by the hemp cultivar and the fertilization regimes. In particular, the length and weight of inflorescences were significantly affected by the interaction of cultivar and fertilization. The fertilization was also a significant factor for all traits except plant height while, cultivar had a significant effect on most of the measured traits $(\mathrm{p}<0.01)$. In general, increasing $\mathrm{N}$ fertilization rate positively impacts hemp biomass yield, stem dry weight, plant height, and inflorescence indices. Biomass yield, stem dry weight and inflorescence weight increased by $37.3 \%, 48.2 \%$ and $16 \%$, respectively, with the application of $240 \mathrm{~kg} \mathrm{~N} \mathrm{ha}^{-1}$ when compared with the unfertilized control. Plant height and inflorescence length increased from 1.66 to $1.76 \mathrm{~m}$ and from 66.2 to $82.9 \mathrm{~cm}$, respectively, with the application of the higher $\mathrm{N}$ rate compared with the control, while there were no significant differences between the fertilization treatments for mean seed weight (Figs. 1 and 2, Table 3).

Average hemp stem yield in Europe was $7.3 \mathrm{Mg} \mathrm{ha}^{-1}$ in 2010 (Carus et al., 2013), so considering the maximum stem yield measured in our trial in the highest $\mathrm{N}$ dose $(11.4,11.1$ and $11 \mathrm{Mg} \mathrm{ha}^{-1}$ for 'Tygra', 'Santhica 27' and 'Futura 75' respectively, Table 3 ), which were slightly lower than the maximum stem yield reported in a previous work that compared hemp yield potential across Europe (Struik et al., 2000), a large potential to improve actual hemp stem yield in Greek conditions can be expected. Furthermore, on average cultivar values for stem yield were 4.94, 6.36 and $7.41 \mathrm{Mg} \mathrm{ha}^{-1}$ for the control, N1 and N2 treatments respectively, indicated nutrient deficiency as reported by Ivanyi and Izsaki (2009).
Lower stem yields from smaller plants were obtained from early flowering cultivars (i.e. 'Bialobrzeskie' and 'Felina 32'). Comparable results were reported by Struik et al. (2000), Aubin et al. (2015), Campiglia et al. (2017) and Tang et al. (2017). The highest biomass yield, stem dry weight and inflorescences weight was observed in the cultivar 'Futura 75 ' under all nitrogen fertilizer rates, which is in agreement with previous research (Sausserde et al., 2013). However, highly variable biomass yields were observed for all genotypes and fertilization treatments, which ranged from $25.4 \mathrm{Mg} \mathrm{ha}^{-1}$ at the control in 'Bialobrzeskie' to $187.7 \mathrm{Mg} \mathrm{ha}^{-1}$ at the highest fertilization dose in 'Futura 75' (Table 3). Increasing the rate of $\mathrm{N}$ fertilizer led to an increase in inflorescence length and weight (Vera et al., 2004; Campiglia et al., 2017). Nitrogen availability has little effect on hemp seed mass and in our study there were no significant

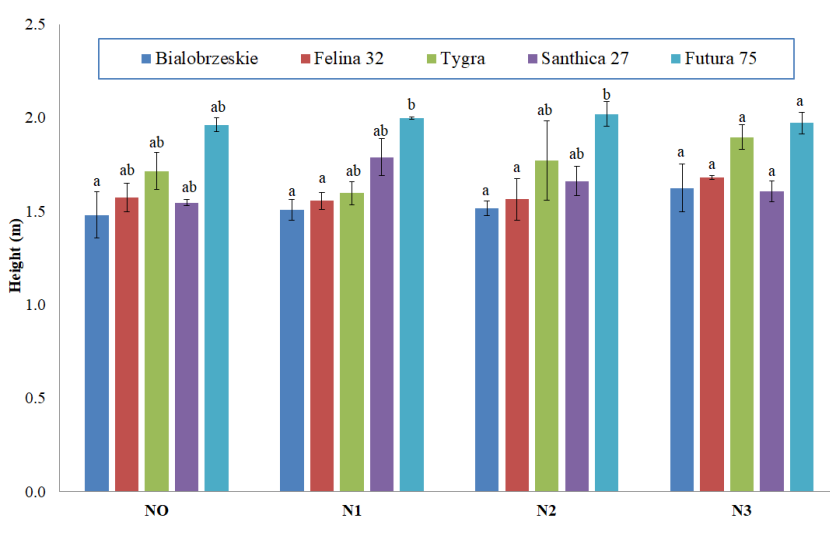

Fig. 1. Plant height (five cultivars) depending on nitrogen fertilization levels (No, N1, N2, N3). Vertical bars indicate the standard errors of the means. Different letters denote significant differences between the cultivar means (LSD test, $\mathrm{p}<0.05$ )

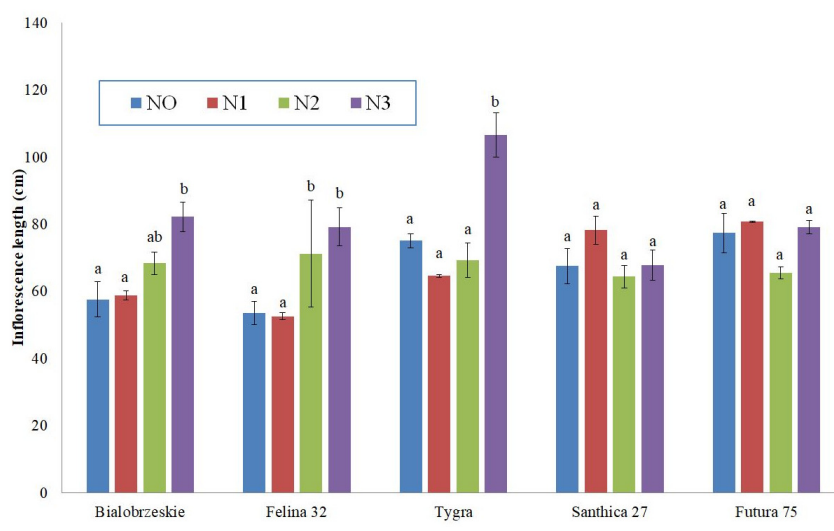

Fig. 2. Inflorescence length (five cultivars) depending on nitrogen fertilization levels (N0, N1, N2, N3). Vertical bars indicate the standard errors of the means. Different letters denote significant differences between the fertilization treatments (LSD test, $\mathrm{p}<0.05$ ) 
Table 3. Average values and analysis of variance for the biomass yield, stem dry weight, inflorescence weight and mean seed weight under different fertilization treatments

\begin{tabular}{|c|c|c|c|c|c|}
\hline Cultivar & $\begin{array}{c}\text { Doze } \\
\mathrm{N}\end{array}$ & $\begin{array}{l}\text { Biomass yield } \\
\left(\mathrm{Mg} \mathrm{ha}^{-1}\right)\end{array}$ & $\begin{array}{l}\text { Stem dry weight } \\
\left(\mathrm{Mgha}^{-1}\right)\end{array}$ & $\begin{array}{l}\text { Inflorescence weight } \\
\left(\mathrm{Mg} \mathrm{ha}^{1}\right)\end{array}$ & $\begin{array}{c}\text { Mean seed weight } 10^{-3} \\
(\mathrm{~g})\end{array}$ \\
\hline \multirow[t]{4}{*}{ 'Bialobrzeskie' } & N0 & $25.3 \mathrm{a}$ & $2.88 \mathrm{a}$ & $10.4 \mathrm{a}$ & 8.65 \\
\hline & N1 & $45.3 \mathrm{ab}$ & $4.44 \mathrm{a}$ & $16.6 \mathrm{a}$ & 7.58 \\
\hline & $\mathrm{N} 2$ & $75.1 \mathrm{bc}$ & $3.17 \mathrm{a}$ & $37.7 \mathrm{~b}$ & 4.48 \\
\hline & N3 & $87.4 \mathrm{c}$ & $5.75 \mathrm{a}$ & $19.1 \mathrm{a}$ & 4.63 \\
\hline \multirow[t]{4}{*}{ 'Felina 32' } & No & $65.1 \mathrm{a}$ & $5.19 \mathrm{a}$ & $33.7 \mathrm{a}$ & 8.52 \\
\hline & N1 & $80.2 \mathrm{a}$ & $6.69 \mathrm{a}$ & $31.6 \mathrm{a}$ & 4.05 \\
\hline & $\mathrm{N} 2$ & $74.9 \mathrm{a}$ & $5.69 \mathrm{a}$ & $15.9 \mathrm{~b}$ & 4.60 \\
\hline & N3 & $87.4 \mathrm{a}$ & $8.50 \mathrm{a}$ & $34.4 \mathrm{a}$ & 4.09 \\
\hline \multirow[t]{4}{*}{ 'Tygra' } & No & $82.3 \mathrm{a}$ & $5.69 a$ & $34.7 \mathrm{a}$ & 7.94 \\
\hline & N1 & $103 \mathrm{a}$ & $7.63 \mathrm{ac}$ & $34.6 \mathrm{a}$ & 5.29 \\
\hline & $\mathrm{N} 2$ & $103 \mathrm{a}$ & $13.9 \mathrm{~b}$ & $32.4 \mathrm{a}$ & 5.15 \\
\hline & N3 & $114 \mathrm{a}$ & $11.4 \mathrm{bc}$ & $39.3 \mathrm{a}$ & 5.37 \\
\hline \multirow[t]{4}{*}{ 'Sanhtica 27' } & No & $50.7 \mathrm{a}$ & $3.56 \mathrm{a}$ & $30.1 \mathrm{a}$ & 3.30 \\
\hline & N1 & $67.1 \mathrm{a}$ & $2.69 \mathrm{a}$ & $33.2 \mathrm{a}$ & 3.89 \\
\hline & $\mathrm{N} 2$ & $67.8 \mathrm{a}$ & $4.81 \mathrm{a}$ & $20.6 \mathrm{a}$ & 8.56 \\
\hline & N3 & $74.1 \mathrm{a}$ & $11.1 \mathrm{~b}$ & $27.9 \mathrm{a}$ & 4.19 \\
\hline \multirow[t]{4}{*}{ 'Futura 75' } & No & $122 \mathrm{a}$ & $7.38 \mathrm{a}$ & $59.5 \mathrm{a}$ & 3.93 \\
\hline & N1 & $168 \mathrm{~b}$ & $10.4 \mathrm{a}$ & $42.6 \mathrm{~b}$ & 11.4 \\
\hline & $\mathrm{N} 2$ & $182 \mathrm{~b}$ & $9.5 \mathrm{a}$ & $65.6 \mathrm{ac}$ & 3.47 \\
\hline & N3 & $188 \mathrm{~b}$ & $11.0 \mathrm{a}$ & $79.7 \mathrm{c}$ & 8.18 \\
\hline \multirow[t]{4}{*}{ Cultivar means } & N0 & $69.1 \mathrm{~A}$ & $4.94 \mathrm{~A}$ & $33.7 \mathrm{AB}$ & 6.47 \\
\hline & N1 & $92.6 \mathrm{~B}$ & $6.36 \mathrm{AB}$ & $31.7 \mathrm{~A}$ & 6.44 \\
\hline & $\mathrm{N} 2$ & $100 \mathrm{BC}$ & $7.41 \mathrm{BC}$ & $34.7 \mathrm{AB}$ & 5.25 \\
\hline & N3 & $110 \mathrm{C}$ & $9.54 \mathrm{C}$ & $40.1 \mathrm{~B}$ & 5.29 \\
\hline FERT & & ${ }^{* * *}$ & $* * *$ & ${ }^{*}$ & ns \\
\hline C & & $* *$ & $* *$ & $* *$ & ns \\
\hline FERT $x$ C & & $\mathrm{ns}$ & ns & $* *$ & ns \\
\hline
\end{tabular}

Note: C, cultivars, FERT, fertilization treatments [control (N0), $120 \mathrm{~kg} \mathrm{ha}^{-1}(\mathrm{N1}), 180 \mathrm{~kg} \mathrm{ha}^{-1}(\mathrm{~N} 2), 240 \mathrm{~kg} \mathrm{ha}^{-1}(\mathrm{~N} 3)$ ].

ns, not significant; significant at ${ }^{*} \mathrm{p}<0.05,{ }^{* *} \mathrm{p}<0.01,{ }^{* * *} \mathrm{p}<0.001$.

Values belonging to the same characteristic with different lower-case letters within a column denote significant differences between fertilization treatments and values with different upper-case letters within a column indicate significant differences between the cultivar means (LSD test, $\mathrm{p}<0.05$ )

differences between the fertilization treatments for mean seed weight (Malceva et al., 2011; Vera et al., 2004; Dan et al., 2015).

According to Amaducci et al. (2015), the flowering stage in hemp is deemed to be the most important event in hemp cultivation, as it affects production in terms of stems, inflorescences and seeds. This study showed that higher $\mathrm{N}$ fertilizer level in hemp has a positive impact mainly on stem yield rather than on inflorescence length and weight (on average $+48.2 \%$, $+20,2 \%$ and $+16 \%$ at $240 \mathrm{~kg}$ of $\mathrm{N} \mathrm{ha}^{-1}$ than the control, respectively). In the Northern Mediterranean environment it seems that it is advisable to use intermediate or late flowering genotypes for stem production, while early flowering genotypes produce more inflorescences and seeds (Campiglia et al., 2017).

\section{Conclusions}

As expected the high $\mathrm{N}$ fertilization level strongly effected stem yield, while inflorescence was less affected. In conclusion, hemp gave a significant yield response to applied fertilizers when levels of plant-available nutrients in soil were low and/or the soil moisture conditions were near optimum for plant growth. Further research should be carried out on different genotypes and to find flexible agronomical practices that are able to improve hemp yields, both for classical and for innovative uses such as the production of high-quality cellulose contained in the stems, the essential oils and resins found in the inflorescences and the high-quality oil and proteins contained in the seeds.

\section{References}

Amaducci S, Errani M, Venturi G (2002). Response of hemp to plant population and nitrogen fertilisation. Italian Journal of Agronomy 6(2):103-111.

Amaducci S, Gusovious HJ (2010). Hemp - cultivation, extraction and processing. In: Müssig J (Ed). Industrial Applications of Natural Fibres: Structure, Properties and Technical Applications. John Wiley \& Sons, UKpp 109-129.

Amaducci S, Scordia D, Liu FH, Zhang Q, Guo H, Testa G, Cosentino SL (2015). Key cultivation techniques for hemp in Europe and China. Industrial Crops and Products 68:2-16.

Aubin MP, Seguin P, Vanasse A, Tremblay GF, Mustafa AF, Charron JB (2015). Industrial Hemp Response to Nitrogen, Phosphorus, and Potassium Fertilization. Crop, Forage \& Turfgrass Management 1:1-10.

Campigia E, Radicetti E, Mancinelli R (2017). Plant density and nitrogen fertilization affect agronomic performance of industrial hemp (Cannabis sativa L.) in Mediterranean environment. Industrial Crops and Products 100:246-254.

Carus M, Karst S, Kauffmann A (2013). The European Hemp Industry: cultivation, processing and applications for fibres, shivs and seeds. European Hemp Industry Association. Retrieved from http://eiha.org/media/2014/10/13-06-European-Hemp-Industry. pdf. 
Cosentino SL, Riggi E, Testa G, Scordia D, Copani V (2013). Evaluation of European developed fibre hemp genotypes (Cannabis sativa L.) in semiarid Mediterranean environment. Industrial Crops and Products 50:312-324

Dan AJ, Duda MM, Moldova C, Florian T (2015). The influence of different seeding space and organic fertilization level upon production and mass of 1000 seeds, recorded in some hemp varieties. Bulletin UASVM Agriculture 72(1):57-60.

Ivanyi I, Izsaki Z (2009). Effect of nitrogen, phosphorus, and potassium fertilization on nutritional status of fiber hemp. Communications in Soil Science and Plant Analysis 40:974-986.

Malceva M, Vikmane M, Stramkale V (2011). Changes of photosynthesisrelated parameters and productivity of Cannabis sativa under different nitrogen supply. Environmental and Experimental Biology 9:61-69.

Prade T, Svensson SE, Andersson A, Mattsson JE (2011). Biomass and energy yield of industrial hemp grown for biogas and solid fuel. Biomass and Bioenergy 35:3040-3049.

Salentijn EMJ,Zhang Q, AmaducciS, Yang M, Trindade LM(2015). New developments in fiber hemp (Cannabis sativa L.) breeding. Industrial Crops and Products 68:32-41.

Struik PC, AmaducciS, Bullard MJ, Stutterheim NC, Venturi G, Cromack $\mathrm{HTH}$ (2000). Agronomy of fibre hemp (Cannabissativa L.) in Europe. Industrial Crops and Products 11:107-118.

Sausserde R, Adamovičs A (2013). Impact of nitrogen fertilizer rates on industrial hemp growth and development. Proceedings of the 19th International Scientific Conference on Research for Rural Development 2013, Latvia University of Agriculture, Jelgava, Latvia pp 50-55.
Sausserde R, Adamovičs A, Ivanovs S, Bulgakov V (2013).Investigations into growing and harvesting industrial hemp. Journal of Research and Applications in Agricultural Engineering 58(4):150-154.

Tang K, Struik PC, Yin X, Thouminot C, Bjelková M, Stramkale V, AmaducciS (2016). Comparing hemp (Cannabis sativa L.) cultivars for dual-purpose production under contrasting environments. Industrial Crops and Products 87:33-44.

TangK, Struik PC, Yin X, Calzolaria D, MusioaS, Thouminot C, Bjelková M, Stramkale V, Magagnini G, Amaducci S (2017). A comprehensive study of planting density and nitrogen fertilization effect on dualpurpose hemp (Cannabis sativa L.) cultivation. Industrial Crops and Products (in press).

Van der WerfHMG, van Geel WCA, van Gils LJC, Haverkort AJ (1995). Nitrogen fertilization and row width affect self-thinning and productivity of fibre hemp (Cannabis sativa L.). Field Crops Research 42:27-37.

Vera CL, Malhi SS, Raney JP, Wang ZH (2004). The effect of N and P fertilization on growth, seed yield and quality of industrial hemp in the Parkland region of Saskatchewan. Canadian Journal of Plant Science 84:939-947.

Vera CL, Malhi SS, Phelps SM, May WE, Johnson EA (2010). N, P and S fertilization on industrial hemp in Saskatchewan. Canadian Journal of PlantScience 90:179-184. 